\title{
Editorial: Branding in the USA - A triumph of technique over substance?
}

I am writing this Editorial as a Briton in the USA living through extraordinary times. While some of this extraordinariness comes from the terrible events of September 11th, 2001, being governed by a judicially appointed (rather than elected) president, and a fast-changing climate of international politics and relations, I am going to focus on the relationship between the recent spate of corporate scandals and branding. I will examine the effect that these business scandals and failures might have on the whole branding 'industry'.

\section{BRANDS}

I have dealt with brands all my working life, and I have observed the initially slow, but now completed, progress towards the point where every substantial company sees itself as being branded or as owning brands. Brands are now ubiquitous. Whereas only five years ago branding consultancies were specialists with years of hard-won craft experience to set them apart, now every marketing consultancy, direct marketing company or advertising agency is a 'brand specialist'. That proliferation of 'expertise' is also to be found on the corporate side of the fence. So, everyone owns brands and the entire marketing industry is comprised of brand experts. Naturally, with this ubiquity of brands and those servicing them you would expect a spectrum of quality and substance to exist. There is no better test for substance than the current shockwaves running through corporate America.

This is an editorial, so I am fortunately excused from having to offer encyclopaedic or definitive coverage of all brand types. I will identify four types of brand for the purposes of this analysis: 'the allegedly crooked', 'the cynical windowdressers', 'the compensators' and last 'the branding heroes'.

\section{'The allegedly crooked'}

First we will look at 'the allegedly crooked'. It would be more accurate and simpler to drop the adverb allegedly, but until some of the current court cases have run their course we will keep the qualification.

My first example of a crooked brand is Andersen, the accountancy firm. What I find most interesting about Andersen is how quickly and completely brand equity of such substance can be annihilated. We are not talking about a Johnny-come-lately brand here; we are talking about the most substantial and lauded brand in the accountancy marketplace. Andersen was formed in 1913 as Andersen, DeLany \& Co by 28-year-old Arthur Andersen. In 1918 it was renamed Arthur Andersen \& Co after its eponymous founder and run by him until his death in 1947 . This was a brand strongly informed, during its formative years, by an intense sense of ethics and technical competence. 
Yet, by the 1990s, it was involved in a growing number of accounting scandals and, by August 2002, it had lost 1,239 of its 2,300 publicly quoted clients. ${ }^{1}$ Its fate as a business and as a brand is sealed. This is an example of the scenario I painted in a previous editorial in The Journal of Brand Management where I predicted that, increasingly, unethical brands would be undermined by customers withdrawing their business quickly and decisively. ${ }^{2}$ This behaviour is to be praised; the customer should always retain the right to walk away the ultimate sanction. In a healthy society, an informed customer or consumer should make a brand that transgresses the law pay. The severity of that transgression will determine how final and complete the customers' sanctions are. But what a waste of a once Titanic brand, a brand that spawned Andersen Consulting (now Accenture) and a brand with close to a century of history behind it.

While Andersen is a story of a long period of growth across the decades, Enron is different. Here is a company with a meteoric rise to self-acclaimed success. Enron was an aggressive builder and communicator of its corporate brand, which proclaimed that Enron dared to challenge conventions and old-fashioned business practices and to redefine them - and how. While the sheer scale and shamelessness of the illegalities at Enron are staggering, here is a company that used branding as part of its corporate affairs strategy to, in effect, deceive customers. Surely, this is the very opposite of what a brand is about. One good definition of a brand (and I accept that there are many good ones) is 'a promise that is kept'. Inherent in this definition is the concept of trust, something that Enron never had any intention of extending to its customers. More informative about Enron's true brand values were the informal brand names given to its energy trading strategies — 'Fatboy', 'Deathstar' and 'Ricochet'. Consider the imagery; one refers to a nuclear bomb dropped on Japan at the close of the Second World War, another to wholesale annihilation by an alien object, and the third to the discharge of a firearm - how appropriate. While many will mourn the passing of Andersen as a brand, there will be many more dry eyes while Enron is laid to rest.

The last two brands that we will look at under the term 'the allegedly crooked' are Qwest and WorldCom, the two large US telecommunications companies. In order that you may appreciate their size, here are some simple statistics. WorldCom carries half the world's Internet traffic, and Qwest is the primary telecommunications service provider in 14 US states. Both of these companies were created through a series of acquisitions - 70 in the case of WorldCom. These were not companies built by slowly and consistently winning business from the customer - customers were purchased. Meanwhile, the brand promise became even more grandiloquent as per the Qwest advertisement promising, to a tired-looking salesman in a motel reception area, "every film ever made available to you online - at the speed of light'. The only thing happening at the speed of light was the loss of investor confidence and the frantic fibre capacity swaps that kept the revenue line growing. Here, as with WorldCom, we have an almost complete divorce between the reality of corporate values and decision- 
making and brand communications. While Enron and Andersen will probably disappear as brands, Qwest and WorldCom may live on, but there will need to be a new contract of trust built between the brand owner and the customer if they are to rebuild their businesses. While Enron and Andersen were more systemically crooked, ordinary Qwest and WorldCom employees worked hard from day to day to service and support customers. The old heart of Qwest, USWest, may allow it to live on.

\section{'The cynical window-dressers'}

The second category of brands is those that I will call 'the cynical windowdressers'. These are companies whose brands are corporate affairs artifacts or imagery weapons used to lay down a smokescreen of acceptability while the company proceeds to operate within the written law, but outside the spirit of the law. We will look briefly at Pacific Gas and Electric Company (PG\&E), SBC Pacific Bell and Merrill Lynch. PG\&E still has an old-fashioned business ethic driven by its semi-monopolistic operations in the Californian gas and electricity markets. While consumers are angry at the company's skyrocketing electricity prices, PG\&E reassures consumers with oldfashioned corporate advertising. PG\&E knows that its customers have little choice, so it focuses its brightest minds on winning corporate affairs battles such as campaigning against a new city-operated electricity grid in San Francisco or defending itself against profiteering during the 2001 Californian energy crisis. I doubt whether many Californians regard the unfeasibly customer-oriented messaging in the advertisements as anything other than money-wasting window-dressing.

Merrill Lynch is now notorious for its internal e-mails denigrating the very stocks it was simultaneously touting to its customers.

Then there is Pacific Bell, now SBC Pacific Bell — the primary telecommunications service provider in California. While their TV advertising praises crews working ' 24 hours a day' for the customer, this clearly was not enough to reduce to less than nine months the fulfilment time for a request for a second $64 \mathrm{kbps}$ dial-up line in our San Mateo home.

The fundamental disjunction between internal behaviour, values, service delivery and the true customer experience undermines the brand considerably. I doubt that these brand owners will show the humility to bring the brand messaging into line with the reality of the brand though.

\section{'The compensators'}

Thirdly, we have 'the compensators'. These are brand owners who imagined that an exciting, well-communicated brand would compensate for a fundamentally flawed business model. In all of my experience working with brands, no brand has been able to provide this compensation. I quote Webvan as an example here in the USA. Webvan did an excellent job of branding itself as the thought leader in the provision of home delivery of groceries in upscale US metropolitan areas. Not only that, but they gained high levels of trial. Many customers were happy with the service and the company's prices too. Webvan was, however, trying to run a business where every additional customer 
simply increased their losses. This resulted in a spectacular and sudden failure where, overnight, the gates of the depots were shut and the Webvan trucks ceased to roll. Here is an example of the brand being welltailored to the customers' needs, but the business model being wildly unrealistic.

\section{'The branding heroes'}

Finally we come to 'the branding heroes'. There are many brands that one could put into this category, and I suspect that if this were a more comprehensive survey, packaged goods and tangible product brands would represent a majority. I will cite just a few in the USA: Samuel Adams beer, Pantene shampoo, McDonald's, CocaCola, Southwest Airlines, FedEx and Dell Computers. I found it hard to build a subjective list with many services or financial companies in it. I suspect that the way in which marketing and branding is built into the DNA of the packaged goods/tangible products companies has some impact on their success. In some industries, branding and indeed marketing is still far from the centre of power.

\section{THE FUTURE}

So, to bring this editorial to a close I will pose a few last questions:

- Will we enter a post-modern world for brands where consumers end up discounting all brands and all marketing communications more comprehensively than they do now, because technique cannot be distinguished from substance?

- Will the bond of trust that is at the heart of the very best brands be ruptured in a more wholesale way?

- Is branding itself set to be a less powerful and economic tool for building businesses?

It is up to every marketing professional, whether on the corporate side or in an agency, to prevent this happening.

\section{Richard Zambuni Editorial Board}

\section{References}

(1) (2002) quoting Auditor-Trak from Strafford Publications, The New York Times, 30th August p. 3, section C.

(2) Zambuni, R. (1999) 'Editorial: Brands and ethics - Oil and water?', see the section 'Does the market punish unethical behaviour?', Journal of Brand Management, Vol. 6, No. 3, pp. 149-151. 